ORGANIZATIONAL CULTURE FOR INNOVATION AND NEW TECHNOLOGICAL BEHAVIOR.

\author{
ENRIQUE CLAVER \\ JUAN LLOPIS \\ DANIEL GARCIA \\ HIPOLITO MOLINA
}

Department of Business Management

University of Alicante (Spain)

Telephone and fax: 34-6-590-36-06.

E-Mail: juan.llopis@ua.es 


\begin{abstract}
Technological innovation requires a technical preparation in material, financial and human resources. However, without a clear corporate culture, the technical side of technological innovation will hardly develop in a satisfactory manner.

In this light, we analyze the origin of a culture based in innovation technology. We also describe, with the support of a large number of empirical and theoretical studies, the most important conditions for the generation of a corporate culture based on technological innovation.
\end{abstract}




\section{ORGANIZATIONAL CULTURE FOR INNOVATION AND NEW TECHNOLOGICAL}

BEHAVIOR.

Nowadays, the so-called "innovative corporations" can hardly be considered as such due to sporadic efforts and inspired actions; rather, innovative processes are achieved through a continued, progressive effort. In this line of thought, Letamendia \& Marzo (1993: 23) point out that a company's innovative action must be a constant one, and not resulting from occasional efforts.

Therefore, we must say that an "innovative attitude" is a key factor for the success of these corporations. It is evident that innovation usually possesses a fairly incidental and capricious character, but it is more evident that successful innovations are the result of a previous disposition to accept the challenge put by any kind of opportunity, in such a way that this coincidental and changeable character mostly does not go beyond mere appearances. In this respect, Porter (1991: 83) stresses the great variety in the origins of innovation, when he remarks that sometimes it results from pressure, necessity or even adverse conditions. The fear of losing, sometimes, proves more powerful than the hope to win.

This issue requires an analysis of the characteristics and requirements of an organizational culture based on technological innovation. The relevance of this matter lies in that firms competing in this way should know which the shared values are.

It is not enough for CEO's to design the actions and behaviours that must be followed, but they should also creat the necessary conditions so that all the staff in the corporation accept and develop the desired organizational project, in order to design new technologies in products and processes. However, it is clear that actions of the high management, both simbolic and technical, set the trends of the corporation, to such an extent that Enz (1994: 11) has observed 
that, if a section disagrees with management philosophy, the management will soon try to change the situation or, at least, reduce the importance of the said section.

This can be noticed even more clearly in firms which have made innovation the key to their competitive advantage. Hardly can a firm be considered innovative without the undoubted compromise of those who make decisions in the economic unit. This is why authors like Foster (1987: 71) and Martínez Sánchez (1994: 71) who are aware of the complexity entailed by any innovative process, especially if it is of a technological character.

In order to analyse all these issues, we shall firstly study the general features of technological and innovative behaviour in corporations, so as to understand the mechanisms that help to outline the "soft" aspects which define technological innovation.

Secondly, we shall define the organizational culture required to develop innovative process related to new technologies, in order to detect which the new tenets of shared knowledge are.

GENERAL ASPECTS OF INNOVATIVE TECHNOLOGICAL BEHAVIOUR IN ORGANIZATIONS.

Firstly, it seems to us necessary to bear in mind the fundamental difference between innovation and technology. In this respect, we may propose a first approach to innovation, as suggested by Drucker (1981: 263), for whom it is not a technical term, but a social and economic one; the criterion therefore is not that of science and technology, but a change in the economic and social atmosphere, a change in the behaviour of individuals as consumers or producers, as citizens, etc. Innovation creates new wealth or new potential for action, rather than new knowledge. 
Of course, this innovation may be of a technological character, but it can also be based on other concepts, such as, for instance, new forms of payments concerning customers, changes in product design and packaging, new forms of distribution, search for methods to motivate the members, etc.

In this light, innovation need not be related to notions like electronic components, biotechnology, engineering, etc., and also the added value which is obtained does not always correspond directly to the amount of resources invested. Thus, Fernández \& Fernández (1988: 131) remark that a seemingly relevant innovation may not go beyond a piece of technical virtuosity, whereas an intellectually less pretentious innovation may lead to a business of large proportions and high profit. Many are the innovations that have failed, simply because they were too forward-looking for their time.

Therefore, we may rearrange our ideas following López Moreno (1996), according to whom innovation may involve technology (both in products and in processes), management methods and social innovation. For our part, we must say that from now on we shall concentrate on the first possibility, that is, on technological innovation.

Within this context, Horwitch \& Prahalad (1996: 216) list three ideal models of technological innovation:

* Model I:Technological innovation processes occurring in high technology small firms.

* Model II:Processes occurring in great corporations, formed by a number of divisions.

* Model III: Processes that can be observed in great consortiums and which usually comprise various industrial sectors. 
The differences between these models are established in terms of technology vs. available capabilities, environment, market, internal processes, and innovation in a strict sense (product line, process or system).

Once we have delimited our area of study, we must admit that all the changes in this field are happening at a great speed, and all economic sectors are involved to some extent. Boddy \& Buchanan (1984: 233) remind us that technological change is a continuous process, in which decisions frequently have to be made on new technology and how to apply it. This is why, although one has no clear notion about the role of this factor, and although its use does not imply a competitive advantage of a firm, such firm will be affected in some way or other.

Corporations supported by technological innovation often can adapt to a new product and/or market by means of a certain diversification. This is feasible given the understanding, the means and, above all, the mental disposition needed for such adaptation. This is what Roberts \& Berry (1985: 3) call "being familiar with technology", or the situation by which there is within a company the awareness of a certain technology, but it need not have been applied.

Another feature observed in these economic structures is pointed out by Hassard \& Sharifi (1994: 140), for whom technological innovation may only flourish when the corporation has a compromise with experimentation, and this is maintained in the long term. Thus, we can see that these values must be upheld for a long period of time, for the results can hardly be detected in the short term.

It is now that we are in a position to understand the definition proposed by Lowe \& Hunter (1992: 251), according to whom corporate innovation implies putting ideas into practice in order to fulfil the tangible and intangible aims of a corporation. These ideas are sometimes new ones, sometimes old ones, but the purpose is always the same: to allow for the creation of 
new and useful products and services, through which the corporation and individuals may express their ideology. Therefore, we can observe that in technological innovation there is a large percentage of the disposition of individuals and their organizational behavior.

Another issue to be raised would be the connection between the size of the corporation and the introduction of technological innovation. Solé \& Valls (1989: 69) believe that large corporations frequently tend to be conservative, and therefore their excessively bureaucratic organizational structures may also prevent the arrival of ideas, and hence of innovation. On the contrary, small firms are believed to possess a great capacity to act with quickness and flexibility concerning the introduction of innovations. From this point of view, this is actually the case, for corporate gigantism usually involves a very slow reaction in many activities, which may hinder any process searching for new possibilities.

A distinctive feature of these firms is that they usually have a decentralized organizational structure, for otherwise the various departments and divisions might not be able to take risks individually. This is due to the fact that this kind of decisions are made by the corporate management, which frequently prevents the detection of some possibilities for useful innovation. Following this line of thought, Peters \& Austin (1986: 120) state that commercial innovations are more likely to be applied in clearly decentralized corporations, even though their development is less coordinated. Innovation is achieved and the main reasons for delay are avoided by entrusting the functions of conception, creation and marketing to small and enthusiastic groups.

Also, it seems logical to believe that, due to the introduction of new technologies, there might be conflict and refusal by the workers, when they are faced with changes in productive and/or administrative processes, in those cases where the workers have not perfectly accepted this orientation (Claver, Gascó \& Llopis, 1996: 371). 
This potential danger, present in every firm, may be diminished to some extent by diagnosing whether the firm has this orientation and, should it not be the case, by observing the degree of confrontation in order to take the necessary measures. Some advice aimed at preventing a conflict between employees and technological innovation is given by Bhalla (1987: 187); according to this author, it would be possible to ease this conflict by using staff or helplines that may envisage the following purposes:

A. Ensure the development and implementation of a large scale business/technology scheme for each business unit.

B. Use each technological organization and its manpower to achieve maximum effectiveness as the basis for the objectives of the business.

C. Develop and manage the technological budget.

D. Maintain a technological vision in order to maximize synergies.

Even assuming that the staff may be receptive towards technological implementation, it can be observed that, due to the changes and complexity such implementation acquires, an exclusive devotion to certain aspects is needed among a considerable percentage of workers. When talking about technological innovation Freije Uriarte (1989: 21) underlines that its knowledge and mastering requires a higher preparation, which in turn leads to specialization and practices that may diminish the adaptability of manpower and the firm itself. In short, it is felt (Claver \& Llopis 1989: 3) that an economic unit that has spread technological innovation among its members must continue to specially nurture such ideas, for otherwise all competitive benefits would be lost.

Another aspect that accounts for the behaviour of firms competing by means of technological innovation is a small fear of taking risks, to such an extent that Ansoff (1979: 120) 
says that "they have an preference towards risks"; indeed, these firms have accepted that success is not achieved at the first attempt. Implicitly, these firms are acknowledging that the future is uncertain. This view is also shared by Adair (1992: 25), Parker (1982: 21) and Peters \& Waterman (1991: 254), amongst others.

In the field of technological innovation, distinctive competence derives from a collective learning, involving how to coordinate production technologies while integrating the manifold technological trends (Pralahad \& Hamel 1991: 51). Barrett (1995: 36) goes as far as to hold that innovation requires an incremental learning process which continuously emphasizes experimentation and systematized thinking, rather than a fragmented one.

Once we have seen all this, we must take into account Levitt's (1991: 54) warning, reminding us that provided people are reasonably free to follow their own inclinations, there will be innovation, for they will find the necessary means to offer improvements. This leads us to start analyzing the features and distinctive traits of this organizational culture.

\section{CORPORATE CULTURE BASED ON TECHNOLOGICAL INNOVATION.}

NEW PROPOSALS FOR SHARED BEHAVIOUR.

Within our attempt to describe the characteristics and conditions that must support a corporate culture based on technological innovation, we shall follow a logical order, beginning by defining corporate culture, that which is based on innovation, the one which is technology-oriented, and finally that which would be defined as culture of technological innovation.

We may define corporate culture as a set of values, symbols and rituals shared by the members of a certain firm, describing the way things are done within an organization when 
solving internal managerial problems, together with those related to customers, suppliers and environment (Llopis Taverner 1992: 22).

Given this definition, we can see, for instance, that without a strong, shared culture which is clearly innovation-oriented, hardly can a firm be competitive due to innovative development (which is also pointed out by Deshpandé, Farley \& Webster 1993: 33). These problems are summarized by Davidson (1992: 14) as follows: "Invoking innovation does not ensure that such notion will be accepted by all participants".

Focusing now on innovation-oriented culture, we may define it, in an initial approach, as the need for the maximum number of innovative ideas to appear within a certain period (FonsBoronat 1992: 16). AECA's (1995: 32) proposal is much more precise: Innovative culture is a way of thinking and behaving that creates, develops and establishes values and attitudes within a firm, which may in turn raise, accept and support ideas and changes involving an improvement in the functioning and efficiency of the firm, even though such changes may mean a conflic with conventional and traditional behavior. For innovative culture to succeed, certain requirements must be met, involving four kinds of attitudes:

* Corporate management is willing to take risks.

* The participation of all members of the firm is requested.

* Creativity is stimulated.

* There is shared responsibility.

A similar view is that of Canalejo (1995: 210), who considers that an innovation-based organizational culture must possess the following values: client-orientation, compromise with objectives, challenge and initiative, exemplary behaviour, team work and permanent improvement. 
To sum up, in order to obtain competitive advantage by means of a search for new business processes, it becomes a must to possess previously a culture supporting such search. In this respect, Vrakking (1990: 99) states that the cultural perception is a prerequisite for innovative behaviour having effective results.

As we have already said in this paper, there may be many ways to innovate, technology being one of them; therefore, we must define the general conditions of an organizational culture based on technology. For this purpose, we shall quote Berg (1985: 244-246), for whom there is a basic difference between technics and technology. Technics means the method, procedure and equipment used in any productive or administrative process; of course, such process (be it productive or administrative) requires a certain degree of skill and art. The knowledge of these skills, art, methods and procedure is technology, and it would constitute a body of knowledge about technics.

Under a different point of view, we should remember the analysis performed by Rogovsky (1988: 8), who distinguishes between cultures oriented towards an imperfect or ambiguous technology and those possessing a perfect or simple technology. In the case of the former, decisions are taken in face-to-face meetings, decentralization has a specific role and the most admired participants are professional staff. On the contrary, those cultures possessing a perfect or simple technology are characterized by standardized rules and procedures concerning calculation, plans and statistics in decision making, the use of centralization in their organizational structure and the preference for technical staff.

After making these distinctions, we are now in a position to establish that the difference between technological culture from technology is that the former is based not upon physical 
reality, but upon the structure of symbolic reality and its daily manifestations in organizational life.

Now we can state that the culture oriented towards technological innovation is the one showing, as its main shared value, first innovation, and then technology. In this light, there is a general belief within the company that, through continued innovation (which will involve the use of technologies, mastered by the whole labour force), such company will protect its position in the market, and even there is a possibility to reach and maintain advantageous positions within the market.

As can be seen in Figure 1, the corporate values based on technological innovation are the intersection of several factors: an innovative culture, a culture based on technology (as a variety of the former) and the CEOs' acceptance, who act as a stimulus and transmission of these beliefs. 


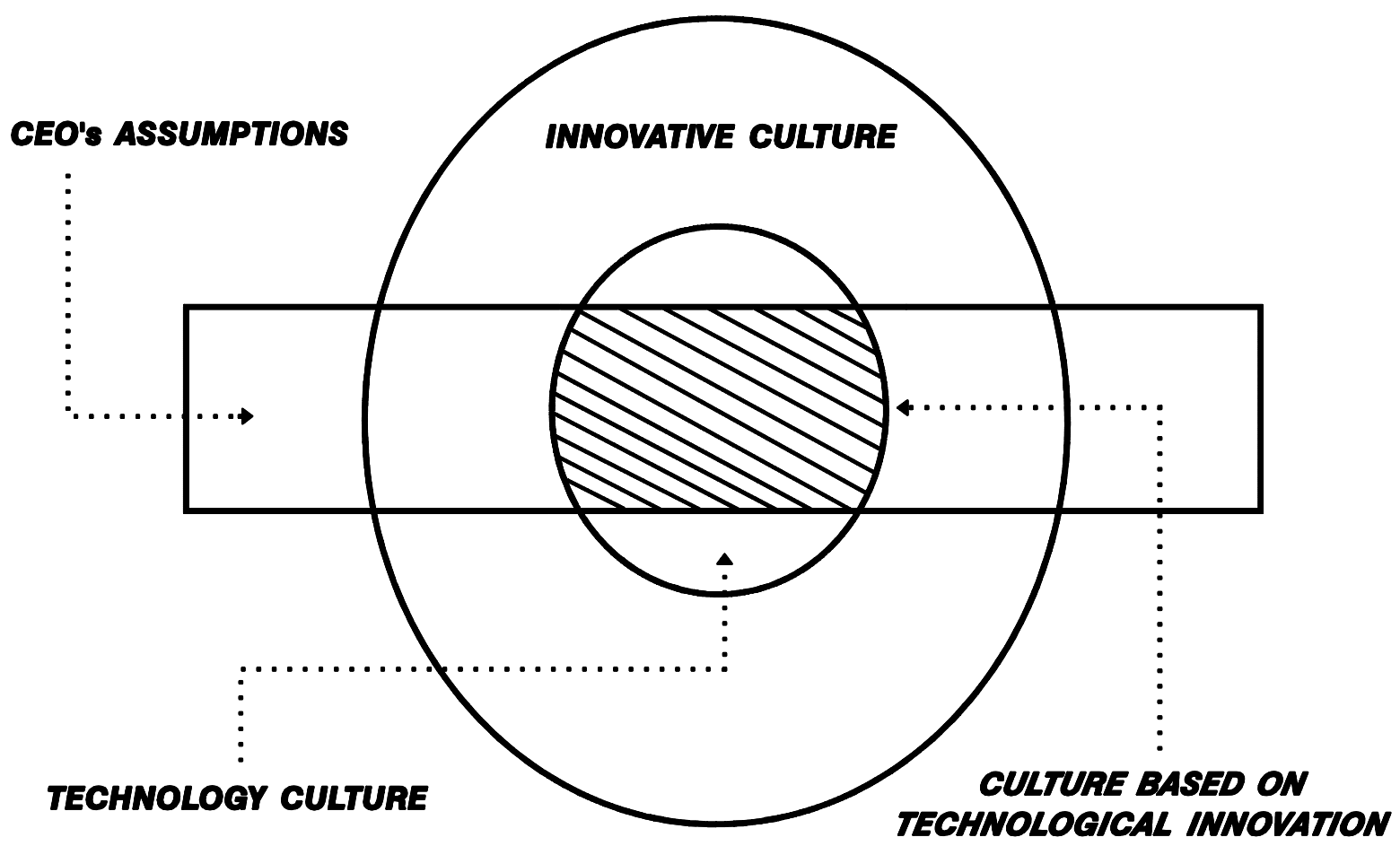

Thus, the way in which competitive advantage is defined, new technology is developed and participants are trained, will be a sound basis for a set of clear corporate values supporting an organizational culture with these values (Mirvis, Sales \& Hackett, 1991: 132); in other words, Dussauge \& Ramanantsoa (1987: 211) tell us that this category of beliefs requires the firm acceptance of all organizational strata.

At the same time, Schneider, Gunnarson \& Niles-Jolly (1994: 21) hold that the employees, within these cultures, must agree with the management's beliefs in the following points:

1. Success derives from an awareness of the market and the needs of end consumers. 
2. What matters is the quality of an idea, not the power and authority of the person who proposed it.

3. In order to obtain good results, creative people need the support and compromise of the organization.

4. Important decisions must be taken gradually, for there usually exist high risk levels in innovative processes.

Despite one of the features of this type of culture is that all organizational participants share the same values. It must not be forgotten that not all innovation cultures are the same (Weiss \& Delbecq 1987:51), and also that, even within the same firm, there may be deviations in this respect in the shape of subcultures (King \& Anderson 1995: 106).

Although these two aspects may coexist (diversity of cultures inside and outside the organization), we shall try to describe some general characteristics deriving from a typical culture based on technological innovation.

An initial trait of all firms possessing a shared view of technological innovation is pointed out by Akash (1993: 60), who follows Wallach (1983). This author states that an innovation-based culture is related to the ethical behaviour of research under two perspectives. On the one hand, the nature of this culture leads the staff to seek results in innovation, without forgetting about ethical principles; on the other hand, the creative nature of this cultural taxonomy leads the management to develop policies that may increase the ethical behaviour of research.

Due to this reason, we may not say that firms oriented towards technological innovation as a shared value do not have the customers in mind, but exactly the opposite, because the internal and external vision of this firms in their activity, makes them search for their consumers' 
needs. Thus, Calori \& Noel (1986: 64) remind us that this type of culture, amongst other features, is characterized by trying to "come closer to consumers". Davis \& Olson (1986: 193) also comment on the "high standard of service" existing in this taxonomy. Finally, within the same line of thought, Humble \& Jones (1989: 46-47) relate this cultural orientation to the purpose of often rendering the present products and services that the firm offers to the market, so as to improve customer satisfaction and obtaining profits.

Another characteristic of this culture is the fact that it allows a considerable degree of autonomy and initiative to the members of the corporation. This results from stimulating and motivating the staff towards technological innovation, refusing bureaucratic notions that may hinder the said cultural taxonomy (Ruiz \& Mandado 1989: 61).

Moving on to another issue, if we relate corporate size to the possibility of developing a culture based on technological innovation, we may initially believe that, the lower the number of people present in the organization, the higher the possibility of these beliefs being accepted. However, Pearson (1989: 89) says that the ambiguity of empirical studies indicates that there is no ideal corporate size when it comes to innovating; this depends on other organizational aspects, such as the corporate structure and culture. Therefore, even if it has a large size, a corporation may develop a successful policy based on technological innovation, provided that, at least, there is a great cohesion among its members. Also, these values must play a predominant role, and a flexible rather than a rigid organizational structure is needed.

A noteworthy feature of this culture is that, although technology is at the forefront of all the shared values, the role of the staff is a fundamental one, especially regarding innovation. Thus, Compain (1986: 145), Fernández \& Bello (1987: 186), Morcillo (1991: 28), Perry (1995: 16), Peters (1989: 377) and Tushman \& Moore (1988: 209), amongst others, believe, despite 
their own different formulations, that the staff is the basic ingredient in any technological innovation process, and therefore of a culture which possesses this orientation.

A much more precise view is that given by Dussauge, Hart \& Ramanantsoa (1992: 203) who, rather than the staff, emphasize the utmost importance of team work, which is reminded through daily rules and customs.

The importance of the human factor in technological innovation leads us to new ideas on shared behaviour, involving the acceptance of change as something inherent to the organization itself. There is a need for a culture that considers change as a usual component, which is a part of day-to-day work, and that raises no obstacles to the alteration of established rules. In other words, the culture must stimulate the process of generating new ideas and applying them either internally or to the market, with the ultimate purpose of changing the markets, adapting the firm to their discontinuities and thus obtaining competitive benefits. This vision of the need to introduce the concept of change in a culture of technological innovation is stressed by Amat (1989: 81), Brannen (1991: 59), Deal \& Kennedy (1985: 113), Fernández Lasquetty (1989: 76), Fernández \& Casino (1988: 107), Foster (1993: 43), Monzón (1995: 123), Santodomingo (1988: 12) and Van Muijen et al. (1993: 245), amongst others. In short, if firms want to be technologically innovative, they must eliminate cultural barriers for change, for they would make them lose their competitive advantage.

\section{CONCLUSIONS}

Technological innovation requires a technical preparation in material, financial and human resources, which will largely determine the success of the aims sought by firms competing in this way. 
However, although this is a fact, it is none the less true also that without clear values and orientations shared by all the members of the corporation, the technical side of technological innovation will hardly develop in a satisfactory manner; in other words, the "hardware" of technological innovation requires the "software" of a corporate culture which is aimed at such innovation.

In this light, we have analyzed (figure 1) the origin of a culture based in innovation technology as an intersection between:

1. The acceptance of CEO's.

2. A culture based on innovation.

3. A culture oriented towards technology as part of innovative culture.

At the same time, we have described, with the support of a large number of empirical and theoretical studies, the most important conditions for the generation of a corporate culture based on technological innovation. Our proposal is based on the following points:

*The corporation has a compromise with experimentation.

*There is a long-term approach to results.

*There is a capacity to act swiftly and flexibly in order to start a process of technological innovation.

*A relative informal atmosphere prevails concerning the relationships between the members of the firm.

*There is a predisposition towards constant learning.

*The organization has a decentralized structure.

*A predisposition to accept risks can be perceived by all members of the corporation. 
*There is a power to adapt to a new product and/or market by means of a relative diversification.

*Systematic thinking prevails over fragmented and sporadic thinking.

*The employees are reasonably free to follow their inclinations in technological innovation.

*Team work is a must.

*Creativity is stimulated.

*Responsibility is shared.

*What matters is the quality of an idea, not the power and authority of the person who proposed it.

*Creative people have the support and stimulus of the corporation.

*Due to the high levels of risk, important decisions are taken gradually.

*A culture based on technological innovation is related to the ethical behaviour in research.

*There is a constant awareness that the ultimate aim of technological innovation is to satisfy consumers' needs.

*Members of the corporation are given a considerable degree of autonomy and initiative.

*Change is accepted as something inherent and usual within the organization.

\section{REFERENCES}

ADAIR, J. (1992). El reto gerencial de la innovación. Legis. Santafé de Bogatá.

AECA (Asociación Española de Contabilidad y Administración de Empresas) (1995). Principios de Organización y Sistemas 2. Innovación en la empresa: factor de supervivencia. Documento 7, Second edition.

AKAAH, I.P. (1993). Organizational culture and ethical research behavior. Journal of the Academy of Marketing Science, 21 (1): 59-63.

AMAT, J.M. (1989). Cómo introducir nuevas tecnologías. Alta Dirección, 145: 77-97.

ANSOFF, I.H. (1979). Strategic management. MacMillam Press. London. 
BARRETT, F.J. (1995). Creating appreciative learning cultures. Organizational Dynamics, 24 (2): 36-49.

BERG, P.O. (1985). Techno-culture: the symbolic framing of technology in a Volvo plant. Scandinavian Journal of Management Studies, 1 (2): 237-256.

BHALLA, S.K. (1987). The effective management of technology. Battelle Memorial Institute. Massachusetts.

BODDY, D. \& BUCHANAN, D. (1984). Information technology and productivity: Myths and realities. Omega. The International Journal of Management Science, 12 (3): 233-240.

BRANNEN, M.Y. (1991). Culture as the critical factor in implementing innovation. Business Horizons, 34 (6): 59-67.

CALORI, R. \& NOEL, R. (1986). Successful strategies in french high technology companies. Long Range Planning, 19 (6): 54-65.

CANALEJO, M. (1995). Innovación organizativa en Alcatel Standard Eléctrica S.A. V Congreso Nacional de la Asociación Científica de Economía y Dirección de la Empresa (ACEDE). San Lorenzo de El Escorial. Madrid. September, vol. 1: 205-216.

CLAVER, E.; GASCÓ, J.L. \& LLOPIS, J. (1996). Los recursos humanos en la empresa: Un enfoque directivo. Second edition. Civitas. Madrid.

CLAVER, E. \& LLOPIS, J. (1989). Cultura industrial y cambio tecnológico, III Congreso Nacional de Economía. La Coruña. December.

COMPAIN, G. (1986). Les regles de la gestion de l'innovation technologique. Revue Française de Gestion. May: 140-149.

DAVIDSON, K.M. (1992). Innovation et fusion d'entreprises aus États-Unis. Culture d'entreprise et innovation. In BERNARD, P.J. \& DAVIET, J.P. (coord.). Presses du CNRS. Lonrai: 91-106.

DAVIS, G.B. \& OLSON, M.H. (1986). Systémes d'information pour le management. Editions G. Vermette Inc, 1. Paris.

DEAL, T.E. \& KENNEDY, A.A. (1985). Culturas corporativas. Fondo Educativo Interamericano. México.

DESHPANDÉ, R.; FARLEY, J.U. \& WEBSTER, F.E. (1993). Corporate culture, customer orientation and innovativeness in japanese firms; a quadrad analysis. Journal of Marketing. 57 (1): 23-37.

DRUCKER, P.F. (1981). Gestión dinámica. Lo mejor de Peter Drucker sobre management. Hispano Europea. Barcelona.

DUSSAUGE, P. \& RAMANANTSOA, B. (1987). Technologie et stratégie d'entreprise. McGraw Hill. Paris. 
DUSSAUGE, P.; HART, S. \& RAMANANTSOA, B. (1992). Strategic Technology Management. John Wiley \& Sons. Chichester. U.K.

ENZ, C.A. (1994). Power and shared values in the corporate culture. UMI Research Press. Ann Arbor. Michigan.

FERNÁNDEZ LASQUETTY, J. (1989). La nueva cultura empresarial. Actualidad Económica. 1640. November: 76.

FERNÁNDEZ, E. \& BELLO, L. (1987). Estrategia tecnológica e innovación empresarial. CYAN. Gijón.

FERNÁNDEZ, E. \& CASINO, A. (1988). La empresa innovadora. Alta Dirección. 138: 105111.

FERNÁNDEZ, E. \& FERNÁNDEZ, Z. (1988). Manual de dirección estratégica de la tecnología. La producción como ventaja competitiva. Ariel. Barcelona.

FONS-BORONAT, J.M. (1992). Gestión de la innovación. Discource of admission to the Real Academia de Ciencias Económicas y Financieras. Barcelona.

FOSTER, R. (1986). Timing technological transitions. In HORWITCH, M. ed. Technology in the modern corporation. A strategic perspective. Pergamon Press. New York.

FOSTER, R. (1987). Innovación. La estrategia del triunfo. Folio. Barcelona.

FREIJE URIARTE, A. (1989). Estrategia y políticas de empresa. Deusto. Bilbao.

HASSARD, J. \& SHARIFI, S. (1994). Cultural barriers to strategic change. In HARDY, C. (ed.) Managing strategic action. Sage. London: 134-142.

HORWITCH, M. \& PRAHALAD, C.K. (1996). Tres modelos de gestión de la innovación tecnológica. Gestión de la innovación tecnológica. Clásicos Cotec. Madrid: 215-232.

HUMBLE, J. \& JONES, G. (1989). Creating a climate for innovation. Long Range Planning. 22 (4): 46-51.

KING, N. \& ANDERSON, N. (1995). Innovation and change in organizations. Routledge. London.

KITCHELL, S. (1995). Corporate culture, environmental adaptation, and innovation adoption: a qualitative/quantitative approach. Journal of the Academy of Marketing Science. 23 (3): 195-205.

LETAMENDÍA, G. \& MARZO, M. (1993). La innovación en la empresa. Cuadernos de Innovación. Diputación Foral de Biskaia. Bilbao.

LEVITT, T. (1991). Reflexiones en torno a la gestión de empresas. Díaz de Santos. Madrid.

LLOPIS TAVERNER, J. (1992). La cultura de empresa: Análisis y enfoque cualitativo para la toma de decisiones. CAM and Universidad of Alicante.

LÓPEZ MORENO, M.J. (1996). Ambiente de las variables estratégicas en la innovación. Seminary in Departamento de Organización de Empresas de Alicante, January. 
LOWE, A. \& HUNTER, R.B. (1992). The role of design and marketing in the culture of innovation. In BAKER, M. (ed.) Perspective on marketing management. John Wiley, Chichester. (2): 247-264.

MARTÍNEZ SÁNCHEZ, A. (1994). Incertidumbre e innovación tecnológica. Alta Dirección, 174: 71-76.

MIRVIS, P.H.; SALES, A.M. \& HACKETT, E.J. (1991). The implementation and adoptation of new technology in organizations: the impact on work, poeple, and culture. Human Resource Management, 30 (1): 113-139.

MONZÓN, J. (1995). El empresario innovador. V Congreso Nacional de la Asociación Científica de Economía y Dirección de la Empresa (ACEDE). San Lorenzo de El Escorial. Madrid. September, (1): 117-129.

MORCILLO, P. (1991). La dimensión estratégica de la tecnología. Ariel. Madrid.

PARKER, R.C. (1982). The management of innovation. John Wiley and Sons. New York.

PEARSON, G.J. (1989). Promoting entrepreneurship in large companies. Long Range Planning, 22 (3): 87-97.

PERRY, T.S. (1995). How small firms innovate. Designing a culture for creativity. Research. Technology Management, 38 (2): 14-17.

PETERS, T.J. (1989). Del caos a al excelencia. Manual para una revolución en la dirección y administración de empresas. Folio. Barcelona.

PETERS, T.J. \& AUSTIN, N.K. (1986). Pasión por la excelencia. Folio. Barcelona.

PETERS, T.J. \& WATERMAN, R.H. (1991). En busca de la excelencia. Fifth edition. Folio. Barcelona.

PORTER, M.E. (1991). La ventaja competitiva de las naciones. Plaza \& Janes. Barcelona.

PRAHALAD, CK. \& HAMEL, G. (1991). La organización por unidades estratégicas de negocio ya no sirve. Harvard-Deusto Business Review, March: 47-64.

ROBERTS, E.B. \& BERRY, C.A. (1985). Entering new business: selecting strategies for success. Sloan Management Review, 26 (3): 3-17.

ROGOVSKY, I. (1988). Diagnóstico de la cultura empresarial: valores y contravalores. XXIII Jornadas de Estudio de la Asociación Española de Dirección de Personal. November. Madrid.

RUÍZ, M. \& MANDADO, E. (1989). La innovación tecnológica y su gestión. Boixareu. Barcelona.

SANTODOMINGO, A. (1988). Cultura empresarial y sistema de información. CHIP, 90: 11-18.

SCHNEIDER, B.; GUNNARSON, S.K. \& NILES-JOLLY, K. (1994). Creating the climate and culture of success. Organizational Dynamics, 23 (1): 17-29. 
SOLÉ, F. \& VALLS, J. (1989). Innovación tecnológica y estrategia empresarial. In: La dirección estratégica de la empresa en el marco económico actual. CAM and University of Alicante: $67-76$.

TUSHMAN, M. \& MOORE, W. (1988). Readings in the management of innovation. Second edition. Pitman. London.

VAN MUIJEN, J et al. (1993). Posibilities for creating innovative cultures in eastern european organizations. In COZIJNSEN, A. \& VARKKING, W. (ed.) Handbook of innovation management. Basil Blackwell, Oxford: 241-253.

VRAKKING, W.J. (1990). The innovative organization. Long Range Planning, 23 (2): 94-102.

WALLACH, E.J. (1983). Individuals and organizations: the cultural match. Training Journal, 37. February: 29-36.

WEISS, J. \& DELBECQ, A. (1987). High-technology cultures and management. Group and Organization Studies, 12 (1): 39-54. 